\title{
New records of oribatid mites from Michoacán state, Mexico
}

\section{Harol Revelo-Tobar ${ }^{1,2}(\infty)$, Edith G. Estrada-Venegas ${ }^{1,2:-\infty}$, Armando Equihua-Martínez ${ }^{1,2}{ }^{1}$, Jorge Valdez-Carrasco ${ }^{10}$}

${ }^{1}$ Colegio de Postgraduados, Campus Montecillo, Montecillo, Mexico state, Mexico. ${ }^{2}$ Private Laboratory of Entomology and Acarology (ENTOMOACARI), Emilio Carranza, La Trinidad, Texcoco, Mexico.

㭋Corresponding author: edith_ev@yahoo.com.mx

Edited by: Gilberto J. de Moraes (Guest Editor)

Received: November 26, 2021. Accepted: December 03, 2021. Published: December 09, 2021.

Abstract. Eleven species of oribatid mites are reported from Michoacán state, Mexico for the first time: Ceratozetidae: unidentified species of Adoribatella Woolley, 1967; Damaeidae: Belbodamaeus (Lanibelba) palaciosi (Iglesias \& Guzmán, 2012); Eremobelbidae: Eremobelba piffli Mahunka, 1985; Microzetidae: Acaroceras (Acaroceras) similis Balogh, 1962; Nothridae: Nothrus anauniensis Canestrini \& Fanzago, 1877; Oppiidae: unidentified species of Cheloppia Hammer, 1971; Oppiella (Oppiella) nova (Oudemans, 1902); Pseudoamerioppia barrancensis (Hammer, 1961); Ramusella (Insculptoppia) merimna (Balogh \& Mahunka, 1977); Wallworkoppia cervifer (Mahunka, 1983); and Scheloribatidae: Scheloribates (Scheloribates) elegans Hammer, 1958. The genera Cheloppia and Adoribatella are reported for the first time from Mexico.

Keywords: Acari, soil mites, Oribatida.

Mexico is the second country with the highest number of records of oribatid mites in Latin America, only surpassed by Brazil (Oliveira et al. 2017). Just over 440 species of 250 genera belonging to 104 families have been reported from Mexico (Palacios-Vargas \& Iglesias 2004). Despite the considerable work done, oribatid diversity in a large part of the Mexican states is still unknown. In the state of Michoacán, only the following taxa have been reported (Salvador de Jesús 2014): Acrotritia curticephala Jacot, 1938 (Euphthiracaridae), the genera Nothrus Koch, 1835 (Nothridae), Tectocepheus Berlese, 1896 (Tectocepheidae), Ceratozetes Berlese, 1908 (Ceratozetidae), Scheloribates Berlese, 1908 (Scheloribatidae), Pergalumna Grandjean, 1936 (Galumnidae) and the families Eremulidae Grandjean, 1965, Oppidae Sellnick, 1937 and Microzetidae Grandjean, 1936. The objective of this publication is to report the oribatid mites found in Michoacán for the first time.

Two sampling sites were considered in the work that generated this publication. Site 1: an intervened primary forest, consisting mainly of Pinus michoacana Martínez (Pinaceae), Quercus rugosa Née (Fagaceae) and scattered understory, located at Nuevo San Juan Parangaricutiro $\left(19^{\circ} 23^{\prime} 27.8\right.$ “N; $\left.102^{\circ} 10^{\prime} 30.8^{\prime \prime} \mathrm{W}\right), 2160 \mathrm{~m}$ above sea level. Site 2: an avocado (Persea americana Mill. Var. Hass, Lauraceae) cultivation with conventional management, located at Uruapan $\left(19^{\circ} 23^{\prime} 47.2^{\prime \prime} \mathrm{N}\right.$; $\left.102^{\circ} 05^{\prime} 58.1^{\prime \prime} \mathrm{W}\right), 1725 \mathrm{~m}$ above sea level. Five soil samples $\left(15 \mathrm{~cm}^{3}\right)$ were collected from each ecosystem and processed in Berlese-Tullgren funnels to extract the oribatid mites. These were counted, macerated in lactic acid and mounted in Hoyer's medium (Walter \& Krantz 2009). The studied material was deposited in the private collection of acarology of the ENTOMOACARI laboratory, at la Trinidad, Texcoco, Mexico state, Mexico. The classification of Shatz et al. (2011) was used for superfamilies and families; while the nomenclature for genera and species, biogeographical distributions and synonyms were obtained from Subias (2020). The taxa collected are subsequently cited.

\section{Ceratozetidae: Ceratozetoidea}

Adoribatella sp. (Fig. 1A).

Material examined: $2 \hat{\sigma}$, from site 1 .

World distribution: Holartic.

Observations: First report of this genus for Mexico.

\section{Damaeidae: Damaeoidea}

Belbodamaeus (Lanibelba) palaciosi (Iglesias \& Guzmán, 2012) (Fig. 1B)

Material examined: $4 \uparrow$ and $1 \hat{\jmath}$, from both sites.

World distribution: Mexico.

Observations: this species has a long flagellate sensillus, 11 pairs of smooth, gradually tapered, radially directed and slightly curved notogastral setae, poorly developed $P$ processes, occasionally present in a beak or rounded. Setae in long, almost as long as the sensillus; setae $r o$ and la smooth. Originally described from specimens collected from Taxco, Guerrero, Mexico.

\section{Eremobelbidae: Amerobelboidea}

\section{Eremobelba piffli Mahunka, 1985 (Fig. 1C)}

Material examined: 4 , from site 1.

World distribution: Neotropical.

Observations: notogaster surface ornamented with irregular longitudinal rows with regular polygonal structure, interlamellar and notogastral setae flagellate. Described from Santa Lucia island. In Mexico, it has been collected from the states of Quintana Roo and Oaxaca (Vázquez 2008; Bernal et al. 2009).

\section{Microzetidae: Microzetoidea}

\section{Acaroceras (Acaroceras) similis Balogh, 1962 (Fig. 1D).}

Material examined: $2 \hat{\jmath}$, from site 1.

World distribution: Neotropical (Peru and Mexico).

Observations: sensillus directed forward, filiform and ciliated. Seta la originating below lamellar cusps, inner tip of cusp pointed, both tips opposite and touching. Setae in extend beyond the lamellar cusps. Notogaster longer than wide. Notogastral setae without surrounding sclerotic rings. Originally described from Cuzco, Peru. First reported from Mexico in the state of Quintana Roo (Vázquez et al. 2016).

\section{Nothridae: Crotonioidea}

Nothrus anauniensis Canestrini \& Fanzago, 1877 (Fig. 1E)

Material examined: 1 q and $1 \hat{\delta}$, from site 1. 
$?=$ Nothrus biciliatus Koch, 1844 sp. inq.

= Nothrus pseudoborussicus Mahunka, 1978

World distribution: Cosmopolitan (except Antarctica): frequent in Palearctic.

Observations: species characterized by having $h 2$ only slightly longer than $p 1$, with expanded end. Originally described from Italy (Canestrini \& Fanzago 1876); previously reported in Mexico from Quintana Roo state (Vázquez 1999).

\section{Oppiidae: Oppioidea}

Cheloppia sp. (Fig. 1F).

Material examined: 2 , from site 1.

World distribution: Tropical (Australian and Neotropical).

Observations: First report of this genus for Mexico.

Oppiella (Oppiella) nova (Oudemans, 1902) (Fig. 1G).

= Oppia aligarhiensis Kardar, 1977

= Oppiella dubia Hammer, 1962

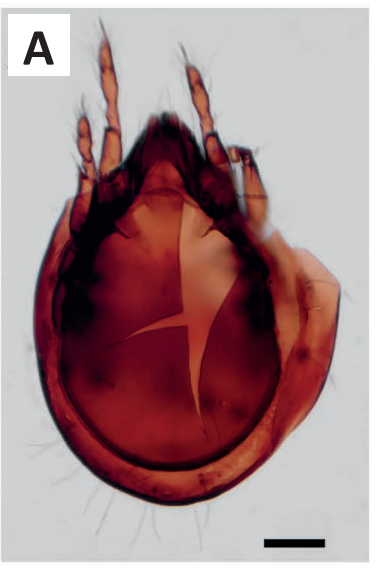

B
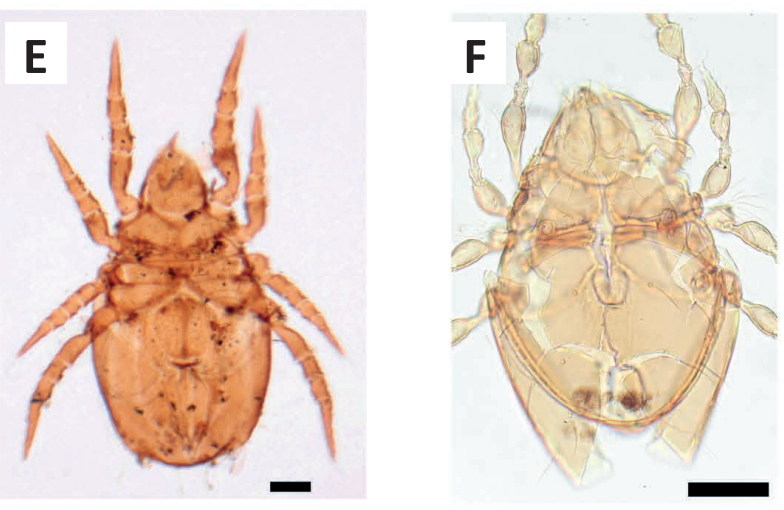

Material examined: $2 \circ$, from site 2.

World Distribution: Cosmopolitan.

Observations: notogaster with one pair of cristas, 4-5 pairs of genital setae. Sensillus fusiform and ciliated. Rostrum without incisions. Prodorsal and notogastral setae long, seta $c 1$ as long as rostral. Originally described from The Netherlands. Hammer (1962) recorded it from Chile near the coast of Puerto Montt. Ojeda (1989) and Iglesias et al. (2019) reported it from Mexico, in Hidalgo and Mexico states.

\section{Pseudoamerioppia barrancensis (Hammer, 1961) (Fig. 1H)}

= Oppia barrancensis paraguayensis Balogh \& Mahunka, 1981

Material examined: $2 \hat{\jmath}$, from site 1.

World distribution: Neotropical, Oriental (Philippines), Ethiopian (Cameroon) and I. Canarias.

Observations: costula, crista and seta in absent; notogastral setae not dilated distally, sensillus slightly dilated and bilaterally ciliated. Cilia as long as the width of the dilated part of the sensillus. Originally described from Lima, Peru. In Mexico, it has been previously recorded from San Cristobal de las Casas, Chiapas (Mahunka 1983).
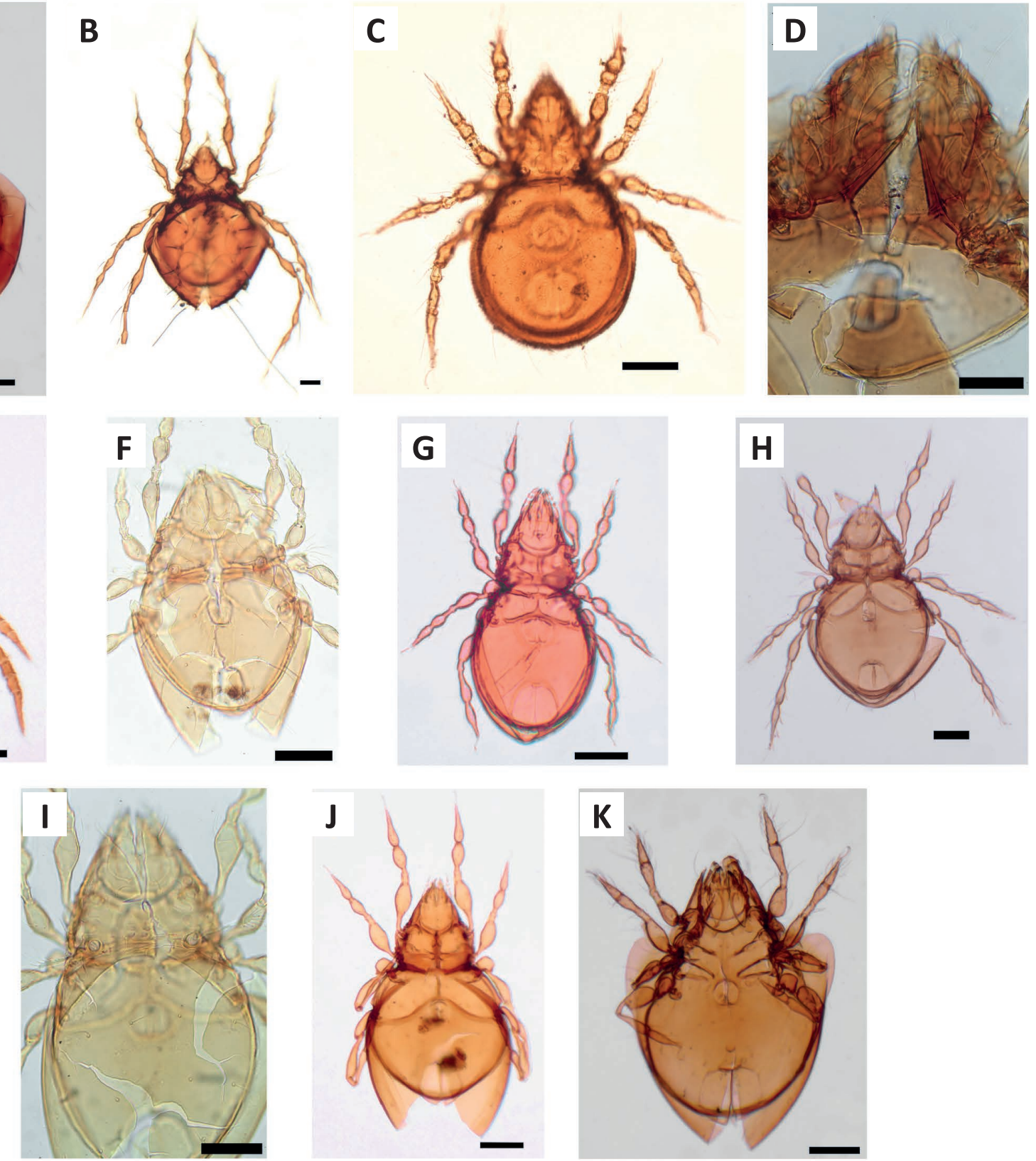

Figure 1. Oribatid mites from the Michoacán state, Mexico. A. Adoribatella sp. (ふ̋), B. Belbodamaeus (Lanibelba) palaciosi (Iglesias \& Guzmán, 2012) ( Eremobelba piffli Mahunka, 1985 ()), D. Acaroceras (Acaroceras) similis Balogh, 1962 ( $)$ ), E. Nothrus anauniensis Canestrini \& Fanzago, 1877 ()), F. Cheloppia sp. (†), G. Oppiella (Oppiella) nova (Oudemans, 1902) (Eremaeus) (†), H. Pseudoamerioppia barrancensis (Hammer, 1961) (Oppia) (ठ̊), I. Ramusella (Insculptoppia) merimna (Balogh \& Mahunka, 1977) (Oppia) ()), J. Wallworkoppia cervifer (Mahunka, 1983) (Oppia) (ð), K. Scheloribates (Scheloribates) elegans Hammer, 1958 (ठ). Scale bar: B-C, E, J= $100 \mu \mathrm{m} ; \mathrm{A}, \mathrm{D}, \mathrm{F}-\mathrm{I}, \mathrm{K}=50 \mu \mathrm{m}$. 
Ramusella (Insculptoppia) merimna (Balogh \& Mahunka, 1977) (Fig. 1I)

Material examined: $3 \circ$ and $1 \hat{\sigma}$, from both sites.

World distribution: Neotropical.

Observations: genital plates with four or five pairs of setae, generally three pairs of distinct sigils between the in setae. Sensillus fusiform and ciliated: from the first to the third short branch, the fourth and fifth much longer and from the fifth to the ninth, gradually shortened. Lamellar ribs poorly developed, cusps absent. Originally described from Brasilia, Brazil. In Mexico, previously reported from Hidalgo state (Iglesias et al. 1999).

\section{Wallworkoppia cervifer (Mahunka, 1983) (Fig. 1J).}

\section{(= Arcoppia longiramosa Woas, 1986)}

Material examined: $5+$ and $8 \hat{\sigma}$, from site 1 .

World distribution: Northern Neotropical.

Observations: six pairs of genital setae, sensillus with five equally long ciliated branches. Prodorsum with characteristic n-shaped ribs. Interlamellar area with 2-3 pairs of sigils arranged irregularly. Ten pairs of notogastral setae, $c$ and $p 1$ smooth and shorter than the remaining setae. Described from specimens from San Cristobal de las Casas, Chiapas state, Mexico.

\section{Scheloribatidae: Oripodoidea}

\section{Scheloribates (Scheloribates) elegans Hammer, 1958 (Fig. 1K).}

Material examined: $5 \hat{\sigma}$, from site 2

World distribution: Tropical: Eastern, Hawaii and Neotropical

Observations: tarsi tridactylous. Sensillus long, apically slightly dilated and stretched into a thin thread, its anterior margin with cilia reaching the lateral margin of the pteromorph. Originally described from Chulumani, Bolivia. Previously reported in Mexico in the states of Oaxaca and Tabasco (Bernal et al. 2009; Palacios-Vargas et al. 2011).

Most of the reported species are widely distributed in the Neotropics. Nothrus anauniensis and $O$. (O.) nova are cosmopolitan. Only females of the latter species were collected, in agreement with its reported asexual reproduction (Brandt et al. 2021). Belbodamaeus (Lanibelba) palaciosi and S. (S.) elegans have been collected in cave soils, agricultural and natural areas, showing great capacity for adaptation to adverse conditions. Acaroceras (Acaroceras) similis, like most species of the genus, is found mostly in soil or litter of undisturbed areas (Mahunka \& Palacios-Vargas 1996).

\section{Acknowledgments}

To Consejo Nacional de Ciencia y Tecnología (CONACYT) and ENTOMOACARI laboratory, for the financial support to the first author. To. G. de Moraes for the valuable recommendations for the improvement of this manuscript.

\section{Authors' contributions}

HRT, EGEV and AEM collected and processed the samples. HRT and EGEV identified the specimens and HRT wrote the manuscript and took the photos. EGEV, AEM. and JVC revised, corrected and translated the manuscript.

\section{References}

Balogh, J. (1962) New Microzetids from eastern Peru (Acari, Oribatei) Annales Historico-Naturales Musei Nationalis Hungarici, 54(7) 405-417.

Balogh, J.; Mahunka, S (1977) New data to the knowledge of the oribatid fauna of the Neogea (Acari). I. Acta Zoologica Academiae Scientiarum Hungaricae, 23(1-2): 1-28.

Bernal, A.; Castaño-Meneses, G.; Palacios-Vargas, J. G.; García, N. (2009) Oribatid mites and springtails from a coffee plantation in Sierra Sur, Oaxaca, Mexico. Pesquisa Agropecuária Brasileira, 44(8):
988-995 doi: 10.1590/s0100-204×2009000800030

Brandt, A.; Van, P.; Bluhm, C.; Anselmetti, Y.; Dumas, Z.; Figuet, E.; François, C.; Galtier, N.; Heimburger, B.; Jaron, K., et al. (2021) Haplotype divergence supports long-term asexuality in the oribatid mite Oppiella nova. Proceedings of the National Academy of Sciences of the United States of America, 118 (38): 1-10. doi: 10.1073/pnas.2101485118

Canestrini, G.; Fanzago, F. (1876) Nuovi Acari italiani. Atti Della Societa Veneto-Trentina Di Scienze Naturali Residente in Padova, 5: 99-111.

Hammer, M. (1958) Investigations on the Oribatid fauna of the andean mountains I. The Argentine and Bolivia. Biologiske Skrifter Kongelige Danske Videnskabernes SelskAB, 10(1): 1-166.

Hammer, M. (1961) Investigations on the oribatid fauna of the Andes Mountains II, Perú. Biologiske Skrifter Udgivet Af Det Kongelige Danske Videnskabernes Selskab, 13(1): 1-207.

Hammer, M. (1962) Investigations on the oribatid fauna of the Andes Mountains III, Chile. Biologiske Skrifter Udgivet Af Det Kongelige Danske Videnskabernes Selskab, 13: 1-96.

Iglesias, R.; Cutz, L.; Palacios-Vargas, J. G. (1999) Estudio preliminar sobre el efecto de los contaminantes del suelo en la fauna edáfica en el estado de Hidalgo. In: Memorias del XXXIV Congreso Nacional de Entomología, pp. 324-327.

Iglesias, R.; Guzman, H. (2012) Nueva especie de Epidamaeus (Oribatei: Damaeidae) del estado de Guerrero, México. Dugesiana, 19(2): 99104.

Iglesias, R.; Palacios-Vargas, J. G.; Castaño, G. (2019) Comparison of oribatid mites from agricultural soils with contrasting irrigation types in Hidalgo State, Mexico: A case study. Revista Mexicana de Biodiversidad, 90(2): 1-12. doi: 10.22201/ ib.20078706e.2019.90.2780

Mahunka, S. (1983) Neue und interessante Milben aus dem Genfer Museum XLV. Oribatida Americana 6: Mexico II (Acari). Revue Suisse de Zoologie, 90(2): 296-298.

Mahunka, S. (1985) Mites (Acari) from St. Lucia (Antilles) 2. Oribatid. Acta Zoologica Hungarica, 31: 119-178.

Mahunka, S.; Palacios-Vargas, J. G. (1996) New species of Microzetidae (Acari: Oribatida) from México. Acta Zoologica Academiae Scientiarum Hungaricae, 42 (4): 251-260.

Ojeda, C. (1989) Aspectos ecológicos de los oribátidos (Acarida: Oribatei) del Edo. de México (su relación con los Céstodos Anoplocephalidae). Ciudad de Mexico: UNAM.

Oliveira, A.R.; Argolo, P. S.; Moraes, G. J. de; Norton, R. A.; Schatz, H. (2017) A checklist of the oribatid mite species (Acari: Oribatida) of Brazil. Zootaxa, 4245(1): 1-89. doi: 10.11646/zootaxa.4245.1.1

Oudemans, A. (1902) Acarologische aanteekeningen. Entomologische Berichten, 6: 15-17.

Palacios-Vargas, J. G.; Iglesias, R. (2004) Oribatei (Acari). In: Llorente Bousquets, J.; Morrone Juan, J.; Yáñez Ordóñez, O; Vargas Fernández, I. (Eds.), Biodiversidad, taxonomía y biogeografía de artrópodos: hacia una síntesis de su conocimiento, pp. 431-468. Ciudad de México: CONABIO.

Palacios-Vargas, J. G.; Castaño-Meneses, G.; Estrada, D. (2011) Diversity and dynamics of microarthropods from different biotopes of Las Sardinas cave (Mexico). Subterranean Biology, 9(1): 113-126. doi: 10.3897/subtbiol.9.2514

Salvador de Jesús, L. A. (2014) Acarofauna asociada al cultivo de aguacate Persea americana Mill. En huertas orgánicas y convencional, en el Municipio de Uruapan, Michoacán México. Texcoco: Colegio de Postgraduados.

Shatz, H.; Behan-Pelletier, V.; OConnor, B.; Norton, R. (2011) Suborder Oribatida van der Hammen, 1968. In: Zhang, Z. (Ed.), Animal Biodiversity: An outline of higher-level classification and survey of taxonomic richness, pp. 141-148. New Zealand: Zootaxa.

Subías, L. S. (2004, actualización 2020) Listado sistemático, sinonímico y biogeográfico de los Ácaros Oribátidos (Acariformes, Oribatida) del mundo (1758-2002). Graellsia, 60 (número extraordinario): 3-305. doi: 10.3989/graellsia.2004.v60.iExtra.218

Vázquez, M. (1999) Catálogo de los ácaros oribátidos edáficos de Sian Ka'an, Q. ROO, México. Chetumal: Universidad de Quintana Roo. 
Vázquez, M. (2008) Microartrópodos edáficos litorales. Dugesiana, 15(1): 7-15.

Vázquez, M.; May, D.; Alamilla, E. (2016) Riqueza específica y biodiversidad de Cozumel, Quintana Roo, México. Teoría y Praxis, 12(19): 137-171. doi: 10.22403/uqroomx/typ19/07

Walter, D. E.; Krantz, G. W. (2009) Collecting, rearing, and preparing specimens. In: Krantz, G. W.; Walter, D. E. (Eds.), A manual of acarology, pp. 83-96. Lubbock: Texas Tech University Press. 